\title{
CORRELATION BETWEEN INTRACELLULAR HEAT SHOCK PROTEIN 70 EXPRESSION AND CERVICAL LYMPH NODES ENLARGEMENT IN NASOPHARYNGEAL CARCINOMA
}

\author{
Achmad C Romdhoni, Sri Herawati, Elida Mustikaningtyas \\ Department of Othorhinolaryngology and Head and Neck Surgery \\ Faculty of Medicine, Universitas Airlangga \\ Dr Soetomo Hospital, Surabaya
}

\begin{abstract}
ABSTRAK
Pertumbuhan tumor dan metastasis pada pasien NPC yang diduga peran beberapa biomarker molekuler yang telah diidentifikasi dalam spesimen tumor pasien dengan NPC. Penelitian intraseluler terbaru menyatakan Hsp70 adalah protein stres yang merupakan faktor utama untuk pertumbuhan, invasi dan metastasis dari NPC. Tujuan dari penelitian ini adalah untuk menganalisis intraseluler Hsp70 ekspresi protein pasien NPC yang berkorelasi dengan pementasan NPC sebagai manifestasi klinis. Penelitian ini menggunakan desain cross sectional. Dalam penelitian ini, spesimen biopsi-parafin tertanam formalin-tetap diperoleh dari 18 NPC dengan semua histopatologi dan klinis dibagi menjadi N0, N1, N2, N3. Ekspresi intraseluler Hsp70 diperoleh dengan imunohistokimia menggunakan antibodi monoklonal Anti Human Hsp70 Antibodi dari Santa Cruz Bioteknologi, California, USA. Penilaian pewarnaan yang dilakukan dengan metode Remmele oleh Histopathologies dokter Konsultan. Tes Spearman digunakan untuk menentukan hubungan antara ekspresi protein Hsp70 intraseluler dan pembesaran nodul serviks dari NPC. Signifikansi statistik didefinisikan sebagai $p<0,05$. Ada 18 pasien NPC pasien yang memenuhi kriteria inklusi dan eksklusi. Menunjukkan negatif intraseluler ekspresi Hsp70 oleh 16,67\% untuk semua sampel yang terdiri 1 pasien N0, 1 pasien dari N1, 1 pasien dari N2, N3 0 pasien. Diikuti oleh 27,78\% positif intraseluler ekspresi Hsp 70 ringan yang terdiri dari 0 pasien N0, 2 pasien dari N1, N2 0 pasien, 3 pasien dari N3. Diikuti oleh 44,44\% moderat positif intraseluler ekspresi Hsp70 yang terdiri 0 pasien N0, 0 pasien dari N1, N2 1 pasien, 9 pasien dari N3. Diikuti oleh 11,11\% sangat positif intraseluler ekspresi Hsp70 yang terdiri 0 pasien N0, 0 pasien N1, N2 0 pasien, 2 pasien dari N3. Spearman hasil tes skor tes $p=0,01$ dengan koefisien korelasi 0,606. Korelasi intraseluler Hsp70 ekspresi protein dengan nodul serviks pembesaran lymphe (N0, N1, N2, N3) pada pasien dengan NPC menunjukkan signifikan ( $p<0,05)$. Kesimpulannya, ada hubungan antara peningkatan ekspresi Hsp70 intacellular dan nodul serviks pembesaran lymphe di karsinoma nasofaring. (FMI 2016;52:24-34)
\end{abstract}

Kata kunci: karsinoma nasofaring, ekspresi protein Hsp70 intrasel, pembesaran nodul limfe servikal

\begin{abstract}
Tumor growth and metastasis in NPC patients suspected role of several molecular biomarkers that have been identified in tumor specimens of patients with NPC. Recent research states intracellular Hsp70 is a stress protein that is a main factor for the growth, invasion and metastasis of NPC. The purpose of this study is to analyze intracellular Hsp70 protein expression of NPC patients which correlate with staging of NPC as clinical manifestation. This study used cross sectional design. In this study, formalin-fixed paraffin-embedded biopsy specimens were obtained from 18 NPCs with all of histopathology and clinically divided into N0, N1, N2, N3. The expression of intracellular Hsp70 was obtained with immunohistochemistry using monoclonal antibody Anti Human Hsp70 antibodi from Santa Cruz Biotechnology, California, USA. Assessment of the staining was performed with Remmele methode by Histopathologies doctor Consultant. The Spearman's test was used to determine the relationship between expression of intracellular Hsp70 protein and enlargement cervical nodul of NPC. Statistical significance was defined as $p<0,05$. There were 18 patients NPC patients that met the inclusion and exclusion criteria. Showed negative intracellular Hsp 70 expression by 16,67\% for all sample in which consist 1 patient of NO, 1 patient of N1, 1 patient of N2, 0 patient of N3. Followed by 27,78\% mild positive intracellular Hsp 70 expression which consist 0 patient of NO, 2 patients of N1, 0 patient of N2, 3 patients of N3. Followed by 44,44\% moderate positive intracellular Hsp 70 expression which consist 0 patient of N0, 0 patient of N1, 1 patient of N2, 9 patients of N3. Followed by 11,11\% strongly positive intracellular Hsp70 expression which consist 0 patient of N0, 0 patient of N1, 0 patient of N2, 2 patients of N3. Spearman test results test scores $p=0.01$ with a correlation coefficient 0.606. Correlation of intracellular Hsp 70 protein expression with enlargement cervical nodul of lymphe $(N 0, N 1, N 2, N 3)$ in patients with NPC showed significant ( $p<0.05)$. In conclusion, there was correlation between increase of the intacellular Hsp70 expression and enlargement cervical nodul of lymphe in nasopharyngeal carcinoma. (FMI 2016;52:24-34)
\end{abstract}

Keywords: Nasopharyngeal carcinoma, Intracellular Hsp70 protein expression, enlargement cervical nodul of lymphe status.

Correspondence: Achmad C Romdhoni, Department of Othorhinolaryngology and Head and Neck Surgery, Faculty of Medicine, Universitas Airlangga, Dr Soetomo Hospital, Jalan Mayjen Prof dr Moestopo 6-8, Surabaya 60286, Indonesia. 


\section{INTRODUCTION}

Nasopharyngeal carcinoma (NPC) is a malignant tumor that is easily infiltrate local tissues, metastasis and tumor growth is rapid. Tumor growth and metastasis in patients with nasopharyngeal carcinoma is still in question until now. Some molecular biomarkers that influence the growth and metastasis of tumor specimens have been identified in patients with NPC. Recent research states Heat shock protein 70 (Hsp70) became the main factor for the growth, invasion and metastasis NPC (Peng et al 2013). Hsp70 is a protein released by cells after exposure to stressors of physical, chemical and biological. Hsp70 function protects tumor cells from lethal damage caused by stress through obstacles in the path of apoptosis. Hsp70 is high in the nucleus is often associated with poor clinical outcomes and a higher frequency of occurrence of metastasis. Studies on NPC has shown that high levels of Hsp70 in the nucleus associated with primary tumor $(\mathrm{T})$ classification of tumors, metastasis, death, and indicates a poor prognosis (Proctor \& Lorimer 2011). But until now the relationship of intracellular Hsp70 expression with stage NPC is still unclear.

The incidence of NPC in the world, an average of 80,000 new cases registered per year $(0.7 \%$ of all cancers). NPC is more common in Chinese or Asian descent, so this poses a serious health problem in southern China. The annual incidence in southern China has reported more than 20 cases per 100,000 population (Neel \& Slavit 1993, Ballenger 1994). In Indonesia, the average incidence rate of 6.2 per 100,000 population, and 13,000 new cases each year NPC. In head and neck malignancies in Indonesia, NPC ranked first with a frequency of about $60 \%$ (Adham et al 2012). Research in China states that there are differences in the expression of Hsp70 with the staging in patients with $\mathrm{NPC}$, which is at stage III + IV expression of Hsp70 6.034 greater than stage I + II (Cai et al 2012). Another study states that there are differences in the expression of Hsp70 in stage I: II: III: IV is 3: 4: 6: 9 (Liao et al 2008).

The role of Hsp70 in tumor growth is by interfering with apoptotic pathway (anti-apoptotic) and serves as a chaperon that ensures proteins fold properly so the tumor cells continue to experience growth (Jaattela et al 1998, Wei 2006). The role of Hsp70 in cancer cells induced by stress. Stress can occur through granzyme pathway, the extrinsic and intrinsic pathways. In the extrinsic pathway, stressors through receptors of tumor necrosis factor- $\alpha$ (TNF- $\alpha$ ) and Fas. While stressors through the intrinsic pathway is a toxin, hypoxia and radiochemotherapy. The number of stressors will cause cell NPC issued several proteins including Fas
Associated Death Domain (FADD), Associated Death Domain Protein (DAXX), and Hsp70. FADD and DAXX that function in cancer cell death process is to function as a protein proapoptosis. Hsp70 is a cell intra stress protein that serves to inhibit apoptosis. The role of intracellular Hsp70 through the barriers to activation of caspase 8 and caspase 3 as well as inhibit the activation of stress kinases, namely c-jun N-terminal kinase (JNK) and Bax is a protein that plays an important role in the apoptosis cascade. The decrease JNK cascade will inhibit tumor cell apoptosis so alive. The process of apoptosis is inhibited NPC will cause cell proliferation and metastasis will experience increased with clinical manifestations in the form of increasingly advanced stage (Sreedhar \& Sermely 2004).

Intracellular stress protein Hsp70 is associated with tumor growth, but until now unknown relationship intracellular Hsp70 expression in patients with various stages of NPC. Based on the above description intend researchers examined the association of intracellular Hsp70 expression at various stages in NPC patients who come for treatment in Otorhinolaryngology Integrated Oncology Clinics (POSA) Dr. Soetomo Hospital. This study aims to analyze the relationship between the expressions of intracellular Hsp70 with enlarged cervical lymph nodes of NPC.

\section{MATERIALS AND METHODS}

This study aims to determine the intracellular Hsp70 protein expression in NPC as well as the correlation between increased expressions of intracellular Hsp70 with stage NPC. Observations made on variables that the event has occurred and with the observation of a moment, so that the design of the study is observational analytic with cross sectional approach.

The study was conducted in Integrated Oncology Clinics (POSA) Otorhinolaryngology Dr. Soetomo Hospital, as a place to conduct a physical examination and determine an enlarged nodule lymph cervical NPC, in the Laboratory of Medical Biology (Biomed) Faculty of Medicine, University of Brawijaya, as a smear immunohistochemistry (IHC) and in the installation of Anatomic Pathology, Faculty of Medicine, Airlangga University, Dr. Soetomo Hospital as a paraffin block creation and assessment intracellular Hsp70 expression.

The population in this study is affordable NPC patients who come for treatment in Otorhinolaryngology POSA Dr. Soetomo Hospital. Samples were 18 patients with NPC were treated first in Otorhinolaryngology POSA and histopathological preparations nasopharynx of patients coming from the Anatomic Pathology Install- 
ation, Faculty of Medicine, Airlangga University/Dr. Soetomo Hospital, taken by consecutive sampling using inclusion and exclusion criteria, then examined the intracellular Hsp70 expression by IHC method in Medical Laboratory, Faculty of Biology, Brawijaya University.

Criteria for inclusion in this study were patients who had paraffin blocks NPC enough to do the examination IHC expression of intracellular Hsp70 and agreed to be included as a sample (informed consent). While the exclusion criteria are paraffin blocks were damaged or ineligible during the process of smear IHC.

In this study our history-taking and clinical examination, including measurement of the cervical lymph nodes enlarged by using the ruler in patients with NPC in Otorhinolaryngology POSA Dr. Soetomo Hospital. Then we do the collection numbers histopathology results of the biopsies of the nasopharynx, looking for paraffin blocks which correspond to the patient in the Installation Pathology (PA) Universitas Airlangga School of Medicine Dr. Soetomo Hospital, paraffin blocks and sent to the Laboratory of Medical Biology Faculty of Medicine, University of Brawijaya to do smear immunohistochemistry with an antibody Hsp70 and Hsp70 expression votes intracellular first by a specialist Pathology.

Rate of intracellular Hsp70 expression was done both by a specialist consultant Anatomical Pathology in Anatomical Pathology Department, Airlangga University Faculty of Medicine, Dr. Soetomo Hospital. Then we calculate the average scale intracellular Hsp70 expression evaluator first with the second marker and record the results of the average scale intracellular Hsp70 expression on the sheet data collectors.

The data obtained in this study were subsequently analyzed by Mann Whitney test was used to determine the relationship between the enlarged cervical lymph nodes NPC with intracellular Hsp70 expression in NPC. Intracellular Hsp70 expression and enlarged cervical lymph nodes assessed as ordinal variables based on the scale described above. The level of significance chosen was $(?)=0.05$.

\section{RESULTS}

The study was conducted in Otorhinolaryngology POSA Dr. Soetomo Hospital from February to April 2014. The samples were collected as many as 20 patients who met the study criteria, from NPC patients who come for treatment to the Otorhinolaryngology POSA. Basic data recorded includes data distribution of patients by sex, age, occupation, address and ethnicity. Immunohistochemical examination results in the form of $\mathrm{Hsp} 70$ expression in NPC assessed the scale of the IRS or the index scale anatomic pathology Remmele by independent consultants. The statistical test used was Spearman's rho test to determine the relationship between the increased expressions of Hsp70 with stage (I, II, III, IV) in the NPC. NPC patient data distribution by age, in Table 1 .

Table 1. Age distribution of patients with NPC

\begin{tabular}{ccr}
\hline Age (years) & Total & $\%$ \\
\hline $20-29$ & 3 & 16.67 \\
$30-39$ & 1 & 5.56 \\
$40-49$ & 7 & 38.89 \\
$50-59$ & 5 & 27.78 \\
$60-69$ & 2 & 11.11 \\
\hline Total & 18 & 100.00 \\
\hline
\end{tabular}

From the above table is the highest known NPC patients in the age group 40-49 years is 7 cases (38.89\%), followed by the age group 50-59 years is 5 cases $(27.78 \%)$ and $20-29$ years are three cases $(16.67 \%)$. The youngest age 22 years old and the oldest 62 years old. Distribution of NPC patients by sex is shown in Table 2.

Table 2. Sex distribution of patients with NPC

\begin{tabular}{lcr}
\hline Sex & Total & $\%$ \\
\hline Male & 10 & 55.56 \\
Female & 8 & 44.44 \\
\hline Total & 18 & 100,00 \\
\hline
\end{tabular}

From the above table was obtained sexes Most are men with a number of 10 patients $(55.56 \%)$ and women as much as 8 patients $(44.44 \%)$. Comparisons between male and female is 1.25: 1. Data base distribution of NPC patients based on ethnicity in Table 3 are as follows:

Table 3. Ethnicity distribution of patients with NPC

\begin{tabular}{lcr}
\hline Ethnicity & Total & $\%$ \\
\hline Javanese & 13 & 72.22 \\
Madurese & 4 & 22.22 \\
Dayaks & 1 & 5.56 \\
\hline Total & 18 & 100.00 \\
\hline
\end{tabular}

From the table above data showed that in patients with NPC ethnic majority are Javanese that 13 patients (72.22\%), the Madurese by 4 patients $(22.22 \%)$ and the Dayak tribe in 1 patient $(5.56 \%)$. Basic data on the distribution of patients NPC-based work can be seen in Table 4. 
Table 4. Occupational distribution of patients with NPC

\begin{tabular}{lcr}
\hline Occupation & Total & $\%$ \\
\hline Farmers & 7 & 38.89 \\
Factory workers & 1 & 5.56 \\
Self-employed & 4 & 22.22 \\
Factory security & 2 & 11.11 \\
Teacher & 1 & 5.56 \\
Housewives & 2 & 11.11 \\
Civil Servants & 1 & 5.56 \\
\hline Total & 18 & 100.00 \\
\hline
\end{tabular}

From the above table showed the highest job is farmers, namely 7 patients $(38.89 \%)$ followed by self-employed amounted to 4 patients $(22.22 \%)$. Basic data on the distribution of NPC patients by histopathology can be seen in Table 5.

Table 5. Histopathological type distribution of NPC patients

\begin{tabular}{ccc}
\hline Histopathology & $\mathrm{N}$ & $\%$ \\
\hline WHO type 1 & 0 & 0 \\
WHO type 2 & 2 & 11.11 \\
WHO type 3 & 16 & 88.89 \\
\hline Total & 18 & 100.00 \\
\hline
\end{tabular}

From the table above are the most histopathological results obtained WHO type 3 as many as 16 patients (88.89\%) followed by 2 WHO type 2 patients $(11.11 \%)$. Distribution increased expression of Hsp70 compared with enlarged cervical lymph nodes in patients with NPC, can be seen in Table 6.

Table 6. Results of the examination increased expression of Hsp70 compared with enlarged cervical lymph nodes in patients with NPC

\begin{tabular}{cccccc}
\hline IRS Scale & N0 & N1 & N2 & N3 & $\%$ \\
\hline- & 1 & 1 & 1 & 0 & 16.67 \\
+ & 0 & 2 & 0 & 3 & 27.78 \\
++ & 0 & 0 & 1 & 7 & 44.44 \\
+++ & 0 & 0 & 0 & 2 & 11.11 \\
\hline Total & 1 & 3 & 2 & 12 & 100.00 \\
\hline
\end{tabular}

Description: Scale IRS negative (-), when the results of IRS scale between $0-1$. Weak positive $(+)$, when the results of IRS scale between 2-3. Moderate positive $(++)$, when the results of IRS scale between 4-8. Strong positive $(+++)$, when the results of IRS scale between 9-12

Hsp70 expression was weakly positive $16.67 \%$ of the whole sample. Hsp70 expression was positive amounting to $27.78 \%$ of the entire sample, and there is an increasing number of cells that give expression weak positive, moderate positive and strong in the enlarged cervical lymph nodes N0, N1, N2, N3.

Hsp70 immunohistochemical examination results on the network NPC identified by their dark brown color staining in the nucleus and cytoplasm of tumor cells. Observation and Hsp70 expression analysis performed with binocular microscope with 400x magnification. The results of immunohistochemical staining are shown in Fig. 1-4.

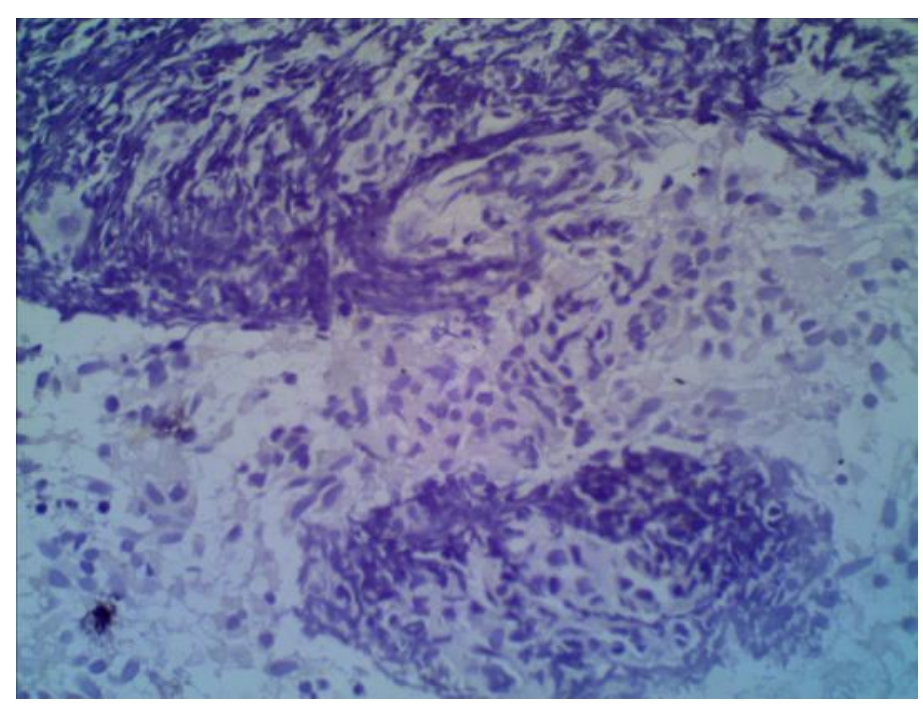

Fig. 1. Results of Hsp70 painting on NPC network with immunohistochemical techniques, expression of Hsp70 negative, no enlarged cervical lymph nodes (N0) 


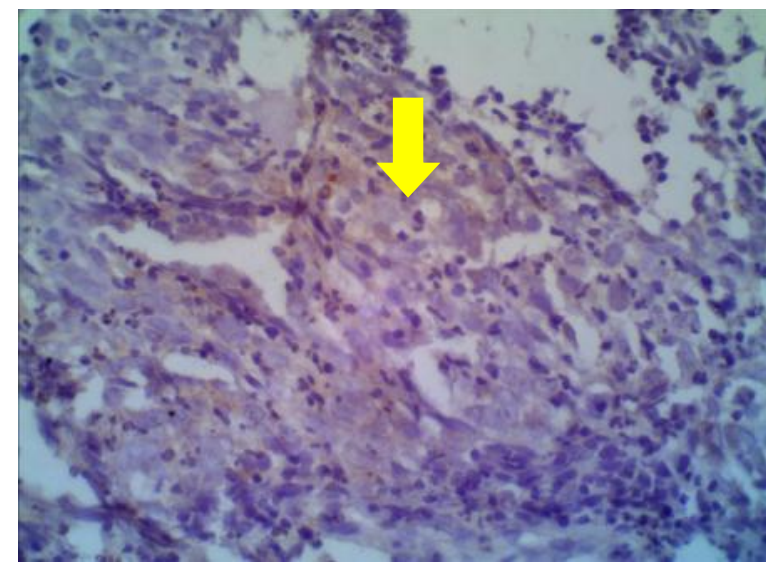

Fig. 2. Results of Hsp70 painting on NPC network with immunohistochemical techniques, weak positive expression of Hsp70, N1

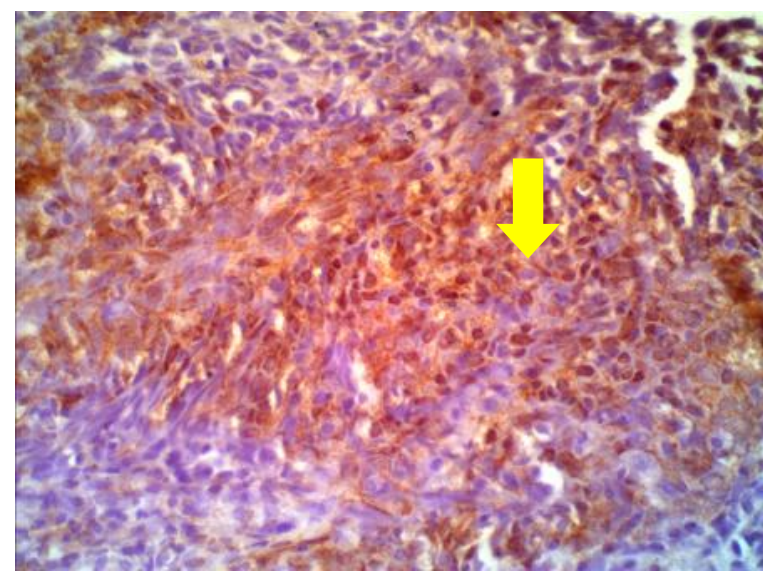

Fig. 3. Results of Hsp70 painting on NPC network with immunohistochemical techniques, positive expression of Hsp70 was, N2

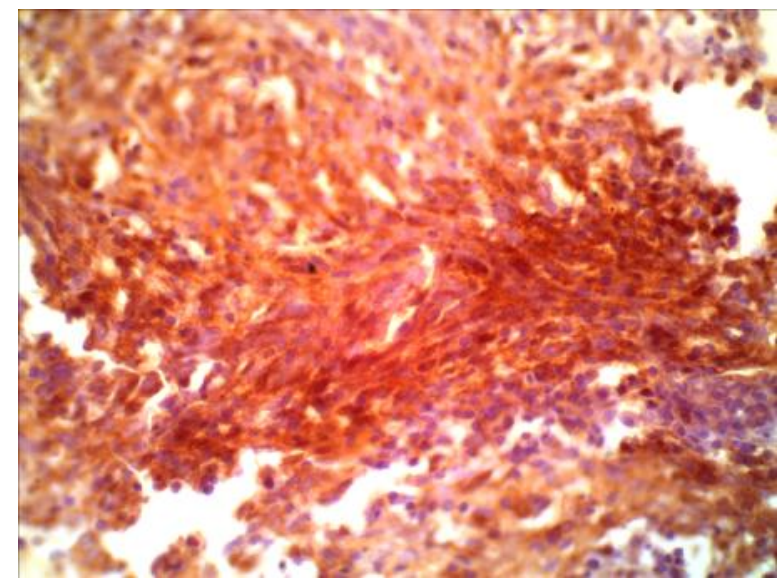

Fig. 4. Results of Hsp70 painting on NPC network with immunohistochemical techniques, strong positive Hsp70 expression, N3
Data statistical analysis of intracellular Hsp70 expression relations with enlarged cervical lymph nodes N0, N1, N2, N3 on NPC calculated by Spearman's test. Spearman's test results to get the value of $p=0.001$ with a correlation coefficient of 0.671 (Appendix 9). Thus the expression of intracellular Hsp70 with stage (std I, II std, std III, std IV) in patients with NPC showed significant correlation $(\mathrm{p}<0.05)$.

\section{DISCUSSION}

This study used cross sectional design therefore variable measurement made in one at a time. Cross-sectional study was done by observing the subject one time only at one point in time and do not follow up. This research is an analytic as investigators tried to find the relationship between variables by analyzing the collected data.

Excess research with cross sectional design among other things allows the retrieval population from the general public, so generalizations adequate, cheap, easy, fast results are obtained, can be used to investigate many variables at once and rarely threatened the sample drop out. It can be used as a basis for further research that is more conclusive.

The data obtained in this study then analyzed statistically. Spearman's test was used to determine the relationship between the increased expression of intracellular Hsp70 with enlarged cervical lymph nodes N0, $\mathrm{N} 1, \mathrm{~N} 2, \mathrm{~N} 3$ in the NPC. The level of significance $(\alpha)=$ 0.05 .

In table 1 the results of this study, obtained the highest distribution of NPC patients are in the age group 40-49 years is 7 cases $(38.89 \% \%)$, followed by the age group $50-59$ years is 5 cases $(27.78 \%$ ) and $20-29$ years is 3 cases $(16.67 \%)$. The youngest age 22 years old and the oldest 62 years old. Results of a previous study of 36 cases of NPC obtained the highest incidence in the age group 40-49 years were 19 cases $(52.77 \%)$, followed by the next $30-39$ years is 8 cases $(22.22 \%)$ and $50-59$ years of age by 6 cases (16.67\%). Distribution of NPC patients by age incidence begins to increase at age 4554 years, then decline. Most NPC found in productive age 30-59 years (approximately 80\%), with a peak between the ages of 40-49 years and the highest incidence are age 40-60 years (Mulyarjo 2002, Kentjono 2010).

Cancer cells arise from normal cells are transformed into malignant, for their spontaneous or induced mutation carcinogen. Since contact with carcinogens and the onset of cancer cells required the induction time 
is long enough, it can be up to 15-30 years (Sukardja 2000). EBV infection as a risk factor NPC has a latency period in the nasopharynx of infected cells, about 20-25 years without symptoms of primary EBV infection in childhood and asymptomatic. NPC process of malignancy occurred after a latent infection, this is likely to cause a high incidence found in the age of 4060 years (Zeng 2010).

In Table 2 obtained distribution of NPC patients by gender is male majority number of 10 patients $(55.56 \%)$ and women as much as 8 patients (44.44\%). Distribution of NPC patients by gender, most common in men $(70 \%)$ in the ratio between men and women is 3 : 1 (Mulyarjo 2002, Kentjono 2010).

The high incidence in men may be due to differences in the habits and the work that led men more frequent contact with carcinogens cause of NPC. Lifestyle habits such as smoking increases the risk of NPC 2-6 times. Exposure to fumes, smoke, dust and chemical gases in the workplace also increases the risk of NPC 2-6 times. While exposure to formaldehyde in the workplace increases the risk of NPC 2-4 times.

In Table 3 obtained distribution of NPC patients by ethnic majority are Javanese that 13 patients $(72.22 \%)$, the Madurese by 4 patients $(22.22 \%)$ and the Dayak tribe in 1 patient $(5.56 \%)$.

Nasopharyngeal carcinoma is a typical disease seen in terms of geography as there are in certain areas with a high prevalence such as in South China, among the Eskimos in the Arctic region, as well as in Southeast Asia. The incidence of NPC remains high among the population of the South China descent living in other countries. In this study there were differences in the distribution of tribes caused the highest rate of residents in the city of Surabaya as research sites are Javanese. In a study of Batak tribe have been found alleles of the gene as a potential cause of vulnerability is the emergence of NPC alleles of the HLA-DRB * 08 (Munir 2009).

In table 4 obtained distribution of NPC patients based on the work the most are farmers, namely 7 patients (38.89\%) followed by self-employed amounted to 4 patients $(22.22 \%)$. Based on the literature that exposure could occur in workers associated with the incidence of NPC is exposure to dust or particles with sizes medium (5-10 $\mu \mathrm{m})$. This is because the particles are easily absorbed by the nasopharyngeal mucosa. Several epidemiological studies have shown the risk factors of NPC increases in workers exposed to wood dust in the period and a certain dose. Other studies have also found an increased risk of NPC occurred in workers who work in environments with combustion products (ashes, charcoal). The ratio of worker exposure cannot be determined because it depends on the frequency and the endemic areas. This could lead to the work of farmer increases the risk factors of NPC although epidemiological may vary based on exposure, duration, dose and NPC endemic areas.

Smokers and occupational exposure to formaldehyde and wood dust is also a risk factor. Formaldehyde is known to be carcinogenic in rat's rice pouch. Particles of smoke coming from the burning of coal, wood and other materials, mostly stored in the nasopharynx. There are several major chemicals are known to cause NPC based occupational exposure, such as bleaching agents, acids and bases, sulfuric acid, ink, formaldehyde and pesti-cides.

In Table 5 obtained distribution of NPC patients by histopathology. WHO mostly histopathological type is type III in the amount of 16 patients $(88.89 \%)$, followed by 2 WHO type II patients $(11.11 \%)$, WHO type I was not obtained. NPC histopathological types most commonly found in Indonesia is WHO type III. The previous study ever conducted in Department of Otorhinolaryngology, Dr. Soetomo Hospital showed similar results (Kentjono 2003). Research in other flashlights in Indonesia also shows the distribution of histopathologic not much different (Soetjipto 1989).

WHO type III nasopharyngeal carcinoma often found in endemic areas because allegedly the main cause of NPC is no exposure to EBV infection. Nasopharyngeal carcinoma associated with EBV is the type of undifferentiated carcinoma (WHO type III) and the kinds of non-keratinizing (WHO type II).

Nasopharyngeal carcinoma in Indonesia is most commonly found types of WHO type III (Adham et al 2012). Soetjipto (1989) conducted a study in the ENTKL RSCM Jakarta (1980-1984) get the kind of WHO type I, II and III respectively as much as $7.87 \%, 2.5 \%$ and $89.63 \%$. Hoesin and Santoso cited Kentjono (2003) conducted a study in 1992 in Anatomical Pathology Medical Faculty Universitas Airlangga/Dr. Soetomo Hospital, get NPC kinds WHO type I, II and III respectively of $17.91 \%, 10.45 \%$ and $71.64 \%$. Kentjono (2003) is based on research in the Outpatient Unit Otorhinolaryngology Dr. Soetomo Hospital 2000 get NPC histopathological types of WHO type I, II and III, respectively for $5.59 \%, 8.04 \%$ and $85.66 \%$. Data basic researches (external factors) do not need to test the homogeneity therefore does not affect the variables studied. 


\section{Increased intracellular Hsp70 expression in nasopharyngeal carcinoma}

In nasopharyngeal carcinoma, increasing intracellular Hsp70 is often attributed to the influence of p53 (wild type). There is a reciprocal relationship between $\mathrm{p} 53$ strong positive (wild type) and intracellular Hsp70. The relationship posed by p53 (wild type) against intracellular Hsp70 showed significant effect $(\mathrm{p}<0.05)$. Protein p53 (wild type) enabled entry into the nucleus becomes a transcription factor for several genes, including genes encoding intracellular Hsp70. Being filled with the intracellular Hsp70 promoter p53 gene (wild type) will cause the active process of transcription, translation process continued. So an increase in p53 protein (wild type) will be followed by an increase in intracellular Hsp70.

In addition, the stress caused by an immunological reaction also increases the intracellular Hsp70, through a cellular stress response to the environment, so that the cells increased the expression Hsf1. Transcription factor gene Hsp Hsfl will push to form the intracellular Hsp70. So the more stress received NPC cells, the higher the intracellular Hsp70 expression in it. This is supported by research conducted by Calderwood et al (2006).

In ovarian cancer research, it was found that intracellular Hsp70 was found positive in $64.7 \%$ of the tumors were positive p53 (wild-type), but the intracellular Hsp70 only 9.5\% expressed in tumors with p53 (wild-type) were negative. In some types of cancer, oncogenesis process of intracellular Hsp70 may be associated with the formation of bonds Hsp-p53 complex. Oncoprotein that often arise in carcinogenesis (eg p53 wild type) can stimulate a response Hsp (Calderwood et al 2006).

Increased Expression of intracellular Hsp70 relationship with an enlarged cervical lymph nodes in Nasopharyngeal Carcinoma Table 6 displays the results of the examination of intracellular Hsp70 expression in patients with NPC enlarged cervical lymph nodes N0, $\mathrm{N} 1$, N2, N3 with Hsp70 expression results in intracellular negative $16.67 \%$, weakly positive for $27.78 \%$ of all samples. Positive intracellular Hsp70 expression was $44.44 \%$ of all samples and strong positive expression of $11.11 \%$. Results with expression weak positive, moderate positive and strong positive cell count obtained in parallel with the enlargement of the cervical lymph nodes, namely in patients with N0 not obtained expression (negative) in one sample. At NPC N1 is 1 sample with negative expression and the second sample was weakly positive expression. At NPC N2 obtained one sample with negative expression and one sample was positive expression. While on the N3 NPC obtained three samples with weak positive expression and 9 samples with positive expression moderate, and 2 samples strongly positive expression.

Test Results Spearman's get $p=0.01$ with a correlation coefficient of 0.606 . Thus, increased expression of intracellular Hsp70 with stage at NPC significant correlation $(p<0.05)$. Thus the hypothesis of this study proved. In this study, a positive correlation between the expression of intracellular Hsp70 (scale IRS) with enlarged cervical lymph nodes in the NPC. The higher the intracellular Hsp70 expression, then the higher the enlarged cervical lymph nodes in the NPC.

The latest research results have been reported by Peng et al (2013) which states intracellular Hsp70 be the main factor for the growth, invasion and metastasis of NPC. Research in China by Cai et al (2012) states that there are differences in the expression of Hsp70 intracellular with staging in patients with NPC, which is at stage III + IV expression of Hsp70 in intracellular larger 6.034 compared to stage I + II (Liao et al 2008).

Hsp have multiple roles as cytoprotection against apoptosis. The elimination of the intracellular Hsp70 expression using antisense oligonucleotides caused inhibition of cell proliferation. In line with this high level of Hsp prevent apoptosis induced by stress. Increased intracellular Hsp70 will reduce or block the activation of caspase and reduce damage to mitochondria and nucleus fragmentation. In this case the intracellular Hsp70 inhibits apoptosis by preventing the activation of procaspase 9 and 3 against apoptosom complex, thus preventing the formation of functional apoptosome (Fulda \& Pervaiz 2010).

Intracellular Hsp70 also plays a role in apoptosis pathway at an earlier stage by preventing the activation of JNK. Intracellular Hsp70 also acts to prevent the activity of effector cells apoptosis. The mechanism of intracellular Hsp70 in protecting cells against apotosis is by binding to proapoptotic proteins such as p53 and cmyc. Intracellular Hsp70 also interact with Bax eg 11 to strengthen the activity of Bcl-2 and Raf-1 (Fulda \& Pervaiz 2010). Some data indicate that the intracellular Hsp70 as well as molecular chaperones, also implicated in protecting tumor cells from DNA damage due to anticancer agents. Hsp several possible mechanisms mediating protection from DNA damage is, involved in the modulation of $\mathrm{p} 53$. There is a reciprocal relationship between p53 strong positive (wild type) and intracellular Hsp70. The relationship posed by p53 (wild type) against intracellular Hsp70 showed significant effect $(\mathrm{p}<0.05)$. In certain cancer patients treated with chemotherapy or radiotherapy, high intracellular Hsp70 
expression and correlated with treatment resistance and poor prognosis (Calderwood et al 2006).

According to the study Bhatt et al (2010) states that Hsp function is expressed cancer for tumor cell proliferation, differentiation, invasion, metastasis, death, and activate the immune system. How Hsp expressed in cancer there has been no clear theory. However, one hypothesis says that Hsp expressed in the tumor micro-environment containing glucose, $\mathrm{pH}$, and oxygen is low. Hsp is a useful biomarker to predict the degree of differentiation and aggressiveness in some types of cancer. Hsp expression are strictly controlled in normal cells, whereas tumor cells often mistake regulation (Cui et al 2009).

Much research has focused on the role of intracellular Hsp70. Research Peng et al (2013) showed that the intracellular Hsp70 was associated with the development of nasopharyngeal carcinoma. Recent data indicate that the intracellular Hsp70 is regulated in nasopharyngeal carcinoma who had metastases and its expression showed metastasis of cancer. The study by Cai et al (2012) suggest that Hsp70 intranuclear positively correlated with the classification $\mathrm{T}, \mathrm{N}$, recurrence, metastasis, clinical stage, and the type of histopathology. Intracellular extracellular Hsp70 is known as a facilitator of the immune response that can interact with receptors on the cell antigens that cause a reaction Hsp70, peptides and antigens. In addition, the intracellular Hsp70 has a strong ability to induce a Tcell response Membranal Hsp70 plays a role in the immune response associated HLA, so linked in the antitumor response in nasopharyngeal carcinoma cells. While Hsp70 intranuclear have the opposite function, namely as a protein that is effective in inhibiting tumor cell death through antiapoptosis and prevent protein misfolding caused by multiple stressors such as heat shock, hypoxia and oxidative stress.

Intracellular Hsp70 role in inhibiting apoptosis via the extrinsic and intrinsic pathways at several levels in the apoptotic pathway. Inhibit the formation of complex functional apoptosom by interacting directly with Apaf1 and prevent the strengthening of procaspase 9 and 3 . Intracellular Hsp70 has the role of anti-apoptosis in caspase independent pathway by binding to AIF is released from mitochondria, therefore restricting translocation into the nucleus (Arya et al 2007). Intracellular Hsp70 can occur translocation from the cytoplasm to the nucleus or nucleolus under conditions of heat stress and serves as a protective barrier against stress-mediated apoptosis and DNA damage, resulting in increased survival of tumor cells (Cai et al 2012).
In general, the expression of Hsp70 was not used for cancer diagnosis markers. However, in some cancer antibodies against Hsp70 significantly as a tumor marker osteosarcoma, ovarian cancer and some other cancers. Various studies also examined the role of Hsp in carcinogenesis. Hsp70 gene polymorphism experienceing indicate abnormal changes that occur during the process of carcinogenesis in some networks. For example, Hsp27 is expressed on endometrial hyperplasia and squamous metaplasia marker for cervical cancer. Hsp70 associated with carcinogenesis in the oral epithelium and as a marker of hepatocellular carcinoma. Hsp so it can be used as a biomarker for several types of cancer.

Hsp70 expression in some studies associated with worse prognosis in cervical cancer, breast cancer, endometrial cancer and bladder cancer. This is consistent with research showing that the intracellular Hsp70 associated with poor differentiation, inhibition of apoptosis, and higher clinical stage, which is a marker for poor clinical response. Conversely, Hsp70 expression are associated with a good prognosis in esophageal cancer, pancreatic cancer and oral cancer. Intracellular Hsp70 expression showed no significant association with prognosis in ovarian cancer, gastric cancer, prostate cancer and leukemia (Calderwood et al 2006).

In this study, cannot get the same amount of NPC patients for each nodule, especially N0 obtained the least amount. This is due to the scarcity of hard and NPC patients who came in and checked out before any enlargement of the lymph nodes of the neck.

\section{CONCLUSION}

There is a correlation between an increased expression of intracellular Hsp70 with enlarged cervical lymph nodes in patients with NPC.

\section{REFERENCES}

Adham M, Kurniawan AN, Muhtadi AI, Roezin A, Hermani B, Gondhowiardjo S, Tan IB, Middeldorp JM (2012). Nasopharyngeal carcinoma in Indonesia: epidemiology, incidence, signs, and symptoms at presentation. Chinese journal of cancer 31, 185-196 
Alderton GK and Bordon Y (2012). Tumor immunotherapy. Nature Reviews Immunology J 12, 237-240

Arya A, Mallik M, Lakhotia SC (2007). Heat shock genes-integrating cell survival and death. Journal of Biosciences 32, 595-610

Azarpira N, Taghipour M, Pourjebely M (2012). Nasopharyngeal carcinoma with cytologic findings. Iranian Red Crescent Medical Journal 14, 492-494

Ballenger JJ (1994). Karsinoma nasofaring. In: Ballenger JJ (ed). Penyakit Telinga, Hidung, Tenggorok, Kepala dan Leher, ed ke-13, Jakarta, Bina Rupa Aksara, p 391-396

Bharatawidjaya KG (2000). Imunologi kanker. In: Bharatawidjaya KG (ed). Imunologi Dasar, 4th ed, Jakarta, Fakultas Kedokteran Universitas Indonesia, p 161-173

Bhatt AN, Mathur R, Farooque A, Verma A, Dwarakanath BS (2010). Cancer biomarkers - Current perspectives. Indian Journal of Medical Research 132, 129-149

Bonorino C and Souza AP (2007). Hsp70 in tumors: friend or foe? In: Calderwood SK, Sherman MY, Ciocca DR (eds). Heat Shock Proteins in Cancer, New York, Spinger, p 191-207

Cai MB, Wang XP, Zhang JX, Han HQ, Liu CC, Bei JX, Peng RJ, Liang Y, Feng QS, Wang HY, Chen LZ (2012). Expression of heat shock protein 70 in nasopharyngeal carcinomas: different expresion patterns correlate with distinct clinical prognosis. Journal of Translational Medicine 10,96

Calderwood SK, Khaleque MA, Sawyer DB, Ciocca DR (2006). Heat shock proteins in cancer: chaperones of tumorigenesis. Trends in Biochemical Sciences 31, 164-172

Cohen I, Rider P, Carmi Y, Braiman A, Dotan S, White MR, Voronov E, Martin MU, Dinarello CA, Apte RN (2010). Differential release of chromatin-bound IL-1 $\alpha$ discriminates between necrotic and apoptotic cell death by the ability to induce sterile inflammation. Proceedings of The National Academy of Sciences 107, 2574-2579

Cong VHF and Ong CK (2008). Nasopharyngeal carcinoma. European Journal of radiology 66, 437-447

Cui XB, Liu W, Li LX, Wang W, Zheng YQ, Guo LL (2009). In vitro study of expression and effects of HSP70/HSP90 in nasopharyngeal carcinoma cells after thermotherapy. Sichuan Da Xue Xue Bao Yi Xue Ban 40, 628-631

Ellis RJ (2005). Molecular chaperones: assisting assembly in addition to folding. In: Henderson B and Pockley AG (eds). Trends in Biochemical Sciences, New York, Cambridge University Press, p 395-401

Fulda S and Pervaiz S (2010). Apoptosis signaling in cancer stem cells. The International Journal of Biochemistry and Cell Biology 42, 31-38
Gastpar R, Gehrmann M, Bausero MA, Asea AAA, Gross C, Schroeder JA, Multhoff G (2005). Heat shock protein 70 surface-positive tumor exosomes stimulate migratory and cytolytic activity of natural killer cells. Cancer Research 65, 5238-5247

Haak J and Kregel KC (2008). A cell stress odyssey. In: Chadwick DJ and Goode J (eds). The Biology of Extracellular Molecular Chaperones, New Jersey, John Wiley \& Sons Ltd, p 3-14

Harun SR, Rahajoe NN, Putra ST, Wiharta AS, Chair I (2002). Uji klinis. In: Sastroasmoro S \& Ismael S (eds). Dasar-dasar Metodologi Penelitian Klinis, Jakarta, Binarupa Aksara, p 144-164

Haug M, DanneckeGE, Holzer U (2007). Impact of Hsp-chaperoned peptides on the MHC class IIdependent presentation and activation of CD4+ T cells in regard of allo and autoantigens. In: Asea AAA and De Maio A (eds). Heat Shock Protein: Potent Mediators of Inflammation and Immunity, 1st ed, New York, Springer, p 275-288

Herr I and Debatin KM (2001). Cellular stress response and apoptosis in cancer therapy. Blood 98, 2603-2614

Hulley SB, Cummings SR, Browner WS, Grady DD, Newman TB (2006). In: Cumming SR (ed). Designing Clinical Research: An Epidemiologic Approach, 3rd ed, Philadelphia, Lippincott Williams \& Wilkins, $p$ 50-57

Jaattela M, Wissing D, Kokholm K, Kallunki T, Egeblad M (1998). Hsp70 exerts its anti-apoptotic function downstream of caspase-3-like proteases. The EMBO Journal 17, 6124-6134

Kaemmerer D, Peter L, Lupp A, Schulz S, Sanger J, Baum RP, Prasad V, Hommann M (2012). Comparing of IRS and Her2 as immnohistochemical scoring schemes in gastroenteropancreatic neuroendocrine tumors. Int J Clin Exp Pathol 5, 187-194

Kawashima (2004). Principle of chemotherapy. In: Perry MC (ed). The Chemotherapy Source Book, 4th ed, Philadelphia, Lippincott Williams \& Wilkins, $p$ 53-64

Kentjono WA (2003). Penatalaksanaan kanker nasofaring masa kini. In: Kentjono WA and Lunardi JH (eds). Naskah Lengkap Simposium Kanker Nasofaring dan Demo Biopsi Nasofaring dengan Teknik Jarum Halus, Surabaya, Dept/SMF Ilmu Kesehatan THT-KL FK Unair/RSUD Dr Soetomo, p 24-44

Kentjono WA (2010). Karsinoma nasofaring: etiologi, gejala, diagnosis, deteksi dini, terapi dan pencegahan. In: Kentjono WA (ed). Pelatihan Deteksi Dini Kanker Nasofaring untuk Dokter Umum di Puskesmas, Surabaya, Dept/SMF Ilmu Kesehatan THT-KL FK Unair/RSUD Dr Soetomo, p 13-41

Kresno SB (2011). Mekanisme signaling transduction inflamasi kronis dengan kanker. In: Kresno SB (ed). Textbook Ilmu Dasar Onkologi, 2nd ed, Jakarta, 
Badan Penerbit Fakultas Kedokteran Universitas Indonesia, p 66-129

Liao Q, Zhao L, Chen X, Deng Y, Ding Y (2008). Serum proteome analysis for profiling protein markers associated with carcinogenesis and lymph node metastasis in nasopharyngeal carcinoma. Research Paper China 25, 465-476

Liao Q, Zhao L, Chen X, Deng Y, Ding Y (2008). Serum proteome analysis for profiling protein markers associated with carcinogenesis and lymph node metastasis in nasopharyngeal carcinoma. Research paper China 25, 465-476

Loeb LA and Harris C (2008). Advances in chemical carcinogenesi: a historical review and prospective. Cancer Res Washington 68, 6863-6872

Moreno M, Lutgendorf SK, Sood AK (2010). Impact of stress on cancer metastasis. Future Oncol 6, 18631881

Mulyarjo (2002). Diagnosis dan penatalaksanaan karsinoma nasofaring. In: Mulyarjo, Soedjak S, Wisnubroto, Harmadji S, Hasanusi R, Artono (eds). Naskah Lengkap Pendidikan Kedokteran Berkelanjutan III Ilmu Kesehatan THT-KL, Surabaya, Laboratorium/SMF Ilmu Penyakit THT-KL FK Unair/RSUD Dr Soetomo, p 38-48

Munir D (2009). Karsinoma nasofaring (Kanker Tenggorok), 1st ed, Medan, USU Press, p 28-38

Nakajima M, Kato H, Miyazaki T, Fukuchi M, Masuda N, Fukai Y, Sohda M, Ahmad F, Kuwano H (2009). Tumor immune systems in esophageal cancer with special reference to heat-shock protein 70 and humoral immunity. Anticancer research 29, 1595-1606

National Comprehensive Cancer Network (2011). NCCN clinical practice guideline in oncology (NCCN guidelines): head and neck cancer. Available from https://www.nccn.org/professionals/physician_gls/f_g uidelines.asp. Accessed December 14, 2014

Neel HB and Slavit DH (1993). Nasopharyngeal cancer. In: Bailey BJ (ed). Head and Neck Surgery Otolaryngology, Philadelphia, JB Lippincot co, p 1257-1272

Nowsheen S and Yan ES (2012). The intersection between DNA damage response and cell death pathways. Experimental Oncology 34, 243-254

Panayi GS, Corrigall VM, Henderson B (2004). Stress cytokines: pivotal proteins in immune regulatory network. Curr Opin Immunol 16, 531-534

Peng Z, Liu N, Huang D, Duan C, Li Y, Tang X, Mei W, Zhu F, Tang F (2013). N,N'-DinitrosopiperazineMediated Heat-Shock protein 70-2 expression is involved in metastasis of nasopharyngeal carcinoma. PLoS ONE 8, e62908

Plati J, Bucur O, Khosravi-Far R (2011). Apoptotic cell signaling in cancer progression and therapy. Integrative Biology 3, 279-296
Pockley AG (2001). Heat shock proteins in health and disease: therapeutic targets or therapeutic agents? Expert rev molecular medicine 3, 1-21

Proctor CJ and Lorimer IAJ (2011). Modelling the role of the Hsp70/Hsp90 system in the maintenance of protein homeostasis. PLoS ONE 6, e22038

Putra ST (2011). Paradikma psikoneuroimunologi menuju ke disciplines-hybrid. In: Putra ST (ed). Psikoneuroimunologi Kedokteran, Surabaya, Airlangga University Press, p 1-18

Soetjipto D (1989). Karsinoma nasofaring. In: Iskandar $\mathrm{H}$ and Munir $\mathrm{M}$ (eds). Tumor Telinga Hidung dan Tenggorok Diagnosis dan Penatalaksanaannya, Jakarta, Fakultas Kedokteran Univesitas Indonesia, p $71-83$

Sreedhar C and Sermely (2004). Heat shock proteins in the regulation of apoptosis: new strategies in tumor therapy a comprehensive review. Journal pharmthera $101,227-257$

Srivastava P (2002). Interaction of heat shock protein with peptides and antigen presenting cells: chaperoning of the innate and adaptive immune responses. Annu rev Immunol 20, 395-425

Sudiana IK (2008). Patologi Molekuler Kanker, Jakarta, Salemba medika, p 20-35

Sukardja IDG (2000). Onkologi Klinik, Surabaya, Universitas Airlangga Press, p 111-112

Susworo R (2007). Radioterapi: Dasar-Dasar Radioterapi, Tata Laksana Radioterapi Penyakit Kanker, Jakarta, Universitas Indonesia Press, p 1-189

Tsan MF and Gao B (2004). Heat shock protein and innate immunity. Cell Mol Immunol I, 274-279

Vakifahmetoglu H, Olsson M, Tamm C, Heidari N, Orrenius S, Zhivotovsky B (2008). DNA damage induces two distinct modes of cell death in carcinomas. Original paper 15, 555-566

Vasef MA and Ferlito A (1997). Clinicopathological consultation: nasopharyngeal carcinoma, with emphasis on its relationship to epstein-barr virus. Ann Otol Rhinol Laryngol 106, 348-353

Vega VL, Silva MR, Frey T, Gehrmann M, Diaz JC (2008). Hsp70 translocates into the plasma membrane after stress and is released into the extracellular environment in a plasma membrane-associated from that activates macrophages. J Immunol 180, 42294307

Wei WI (2006). Nasopharyngeal cancer. In: Bailey BJ, Johnson JT, Newlands SD (eds). Head and Neck Surgery - Otolaryngology, 4th edition, Philadelphia, Lippincott Williams \& Wilkins, p 1658-1670

Wijaya FF, Santosa LA, Waspadji S (2009). Role of heat shock protein in insulin resistance. Majalah kedokteran Indonesia 58, 122-127

Withers RH and McBride WH (1998). Biologic basis of radiation therapy. In: Perez CA and Brady LW (eds). Principles and Practice of Radiation Oncology, 3rd 
ed, Philadelphia, Lippincott Williams \& Wilkins, p 79-116

Zeng MS (2010). Pathogenesis and etiology of nasopharyngeal carcinoma. In: Lu JJ, Cooper JS, Lee
AWM (eds). Nasopharyngeal Cancer Multidisciplinary Management, New York, Springer, p 12-20 